\title{
RASCH MODEL: IDENTIFIKASI KEMAMPUAN HABITS OF MIND PESERTA DIDIK SMA
}

\author{
R. Mulvia ${ }^{1 *}$, S. Ulfa ${ }^{2}$, W.N. Ady ${ }^{2}$ \\ ${ }^{1}$ Program Studi Pendidikan Fisika, Universitas Garut \\ Jalan Raya Samarang No. 52A, Garut \\ email: rahmadhanimulvia@uniga.ac.id \\ ${ }^{2}$ Program Studi Pendidikan Fisika, Universitas Garut \\ Jalan Raya Samarang No. 52A, Garut
}

\begin{abstract}
Abstrak
Tujuan penelitian adalah untuk mengidentifikasi kemampuan habits of mind yang dimiliki peserta didik SMA dengan analisis Rasch Model. Habits of mind adalah kemampuan perilaku cerdas paling tinggi yang dimiliki peserta didik sebagai hasil belajar jangka panjang pada proses pembelajaran sehingga dijadikan indikator kesuksesan dalam penyelesaian masalah. Habits of mind terbagi menjadi tiga kategori: berpikir kritis, berpikir kreatif dan regulasi diri. Untuk mencapai tujuan, Rasch Model digunakan untuk menganalisis kemampuan habits of mind peserta didik SMA. Hal ini dikarenakan, Rasch Model memiliki asumsi invariansi parameter artinya parameter butir soal tidak bergantung pada parameter kemampuan peserta didik dan parameter kemampuan peserta didik tidak bergantung pada parameter butir soal. Penelitian ini menggunakan metode deskriptif kuantitatif dengan partisipan 36 peserta didik SMA yang berumur 16-17 tahun dan dipilih secara random sampling. Instrumen yang digunakan adalah kuesioner yang terdiri dari 15 pernyataan mencakup setiap kategori habits of mind dan dinyatakan layak oleh ahli. Hasilnya, kemampuan habits of mind yang dimiliki peserta didik SMA berbeda untuk setiap kategori. Sebagian besar dari partisipan memiliki habits of mind-berpikir kritis dan habits of mind-berpikir kreatif di atas rata-rata dibandingkan habits of mind-regulasi diri. Oleh karena itu, untuk meningkatkan habits of mind dapat melalui pembelajaran dengan strategi asesmen formatif yaitu feedback, self-assessment dan peerassessment.
\end{abstract}

Kata kunci: habits of mind; Peserta Didik SMA; Rasch Model.

\section{Pendahuluan}

Habits of mind adalah perilaku cerdas yang dimiliki oleh peserta didik dalam menyelesaikan masalah sebagai hasil dari salah satu dimensi proses belajar jangka panjang (Marzano, dkk., 1993; Marzano \& Pickering, 1997; Costa \& Kallick, 2000; Campbell, 2006). Masalah adalah segala sesuatu yang tidak secara langsung diketahui jawabannya tetapi harus diselesaikan dengan suatu proses seperti pertanyaan, tugas, penjelasan dari peristiwa, dan lainnya (Costa \& Kallick, 2000; Susilowati, dkk., 2018). Peserta didik yang memiliki habits of mind yang baik dapat memiliki kemampuan pemecahan masalah yang baik. Hal tersebut dikarenakan dalam menyelesaikan masalah terdapat proses menalar dan menerapkan pengetahuan yang menggunakan keterampilan, sikap, pengetahuan, kepribadian diri, pengalaman masa lalu, dan berbagai disposisi paling tinggi lainnya atau dikenal dengan habits of mind (Costa \& Kallick, 1991; Costa \& Kallick, 1998; Bee, Seng \& Jusoff, 2013; Hizqiyah, dkk., 2018; Hayat, dkk., 2018). Oleh karena itu, beberapa ahli 
menyatakan bahwa habits of mind merupakan pola perilaku cerdas paling tinggi yang dapat menentukan kesuksesan seseorang (Marzano, 1993; Marzano \& Pickering, 1997; Costa \& Kallick, 1991; Neo \& Cheung, 2005; Campbell, 2006).

Habits of Mind memiliki peranan penting dalam dimensi belajar jangka panjang dikarenakan melatarbelakangi dimensi belajar lainnya, lihat Gambar 1.

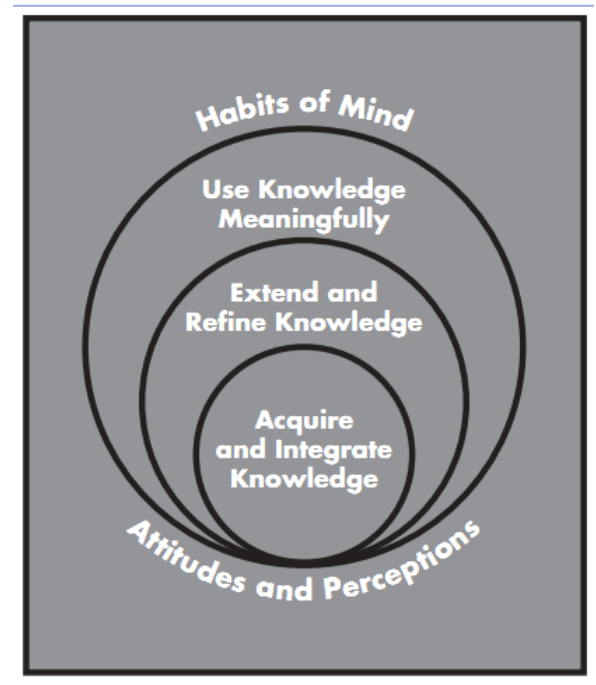

Gambar 1. Dimensi belajar Marzano

Gambar 1, menunjukkan semua dimensi belajar dilatarbelakangi oleh dimensi 1 (sikap dan persepsi) dan dimensi 5 (habits of mind). Hal ini dikarenakan jika peserta didik memiliki sikap dan persepsi yang positif maka ia berkecenderungan akan lebih mudah untuk belajar sehingga banyak pengetahuan yang diperolehnya. Sebaliknya, jika peserta didik memiliki sikap dan persepsi yang negatif maka ia berkecenderungan akan memiliki kesulitan dalam belajar sehingga sedikit ilmu pengetahuan yang diperolehnya. Demikian pula dengan habits of mind, jika peserta didik menggunakan habits of mind dalam pembelajaran, maka ia akan memfasilitasi pembelajarannya sehingga diperoleh pengetahuan yang menyeluruh. Sebaliknya, jika peserta didik tidak menggunakan habits of mind dalam pembelajaran, maka ia akan menghalangi pembelajarannya sehingga tidak diperoleh pengetahuan yang menyeluruh.

Peserta didik memiliki tugas untuk memperoleh dan mengintegrasikan pengetahuan yang dimilikinya (dimensi 2) sehingga dapat mengintegrasikan pengetahuan baru dan kemampuan yang dimilikinya. Pada tahap ini terjadi interaksi antara pengetahuan baru dan pengetahuan lama sehingga peserta didik melakukan proses pengembangan pengetahuan barunya. Proses tersebut merupakan kegiatan berpikir dalam memperluas dan menyaring pengetahuannya (dimensi 3). Kedua tahapan tersebut terjadi jika peserta didik menggunakan pengetahuan secara bermakna (dimensi 4) sehingga tujuan dari pembelajaran dapat tercapai. Oleh karena itu, pada Gambar 1 lingkaran dimensi 2, 3, dan 4 saling tumpang tindih.

Dari beberapa ahli pendidikan, Marzano (1993) membagi habits of mind menjadi tiga kategori yaitu berpikir kritis, berpikir kreatif dan regulasi diri. Berpikir kritis meliputi akurat dan mencari akurasi; jelas dan mencari kejelasan; bersifat terbuka; menahan diri dari sikap impulsif; mengambil posisi ketika informasi memerlukannya; serta peka terhadap perasaan dan tingkat pengetahuan orang lain. Berpikir kreatif meliputi berpartisipasi secara intens dalam tugas meski jawaban atau solusi belum jelas; memaksimalkan pengetahuan dan kemampuannya; menghasilkan, meyakini dan mempertahankan standar evaluasinya; serta menghasilkan cara baru dalam memandang situasi di luar batasan kebiasaan umum. Regulasi diri meliputi menyadari pemikirannya sendiri; membuat rencana secara efektif; mengenali dan menggunakan sumber yang diperlukan; peka terhadap umpan balik; dan mengevaluasi keefektifan tindakannya. Ketiga kategori tersebut 
mengarah pada keterampilan cara berpikir dalam pembelajaran abad 21 yang dikemukaan oleh Griffin, dkk (2012).

Habits of mind yang dimiliki oleh peserta didik dapat digali, dilatih, dikembangkan dan dibentuk menjadi lebih baik melalui pembelajaran (Marzano, 1992). Salah satunya dengan menggunakan berbagai strategi asesemen yang menunjukkan kinerja peserta didik dalam pembelajaran (Marzano, 1993; Volkmann \& Eichinger, 1999; Hofsein \& Mamlok-Naaman, 2007; Nahadi, dkk., 2015; Gloria, dkk., 2017). Asesmen tersebut merupakan asesmen alternatif. Asesmen alternatif adalah asesmen yang dinilai bukan dengan pilihan ganda tetapi bentuk lainnya seperti tugas kinerja, portofolio, rubrik, observasi, jurnal, wawancara dan lainnya (Hamayan, 1995; Marzano, 1993; Dikli, 2003). Asesmen tersebut merupakan asesmen yang dapat memberikan informasi lebih mendalam tentang kemampuan yang dimiliki peserta didik (Sadler, 1989; Black \& William, 1998; Dikli, 2003; Panadero \& Romero, 2014; Hwang, dkk., 2014; Shavelson, dkk., 2018).

Asesmen dilakukan untuk mengetahui hasil dari proses pembelajaran. Pembelajaran pada penelitian ini yaitu pembelajaran fisika. Oleh karena itu, asesmen untuk kemampuan habits of mind yang dimiliki oleh peserta didik dalam menyelesaikan masalah yang berkaitan tentang fisika dalam kehidupan sehari-hari sebagai hasil dari pembelajaran.

Untuk mengetahui kemampuan habits of mind peserta dapat dilakukan dengan menggunakan analisis Rasch Model. Rasch Model adalah salah satu model analisis teori modern yang merupakan pengembangan dari item response theory (Sumintono \& Widhiarso, 2015). Jenis data yang dapat dianalisis dengan Rasch Model berupa data dikotomi dan data politomi. Data yang diperoleh dari penelitian ini adalah data politomi yang setiap soal memiliki nilai rentang yang sama (Muraki \& Bock, 1997 dalam Retnawati, 2014; Bjorner, dkk., 2003; Bolt, dkk, 2004; Sumintono \& Widhiarso, 2015; Jiang, dkk., 2016; Kuo \& Sheng; 2016).

Analisis dengan menggunakan Rasch Model ini merupakan solusi untuk mengatasi masalah pengukuran pada teori klasik (DeMArs, 2010; Qaseem, 2013; Kohli, dkk., 2014; Retnawati, 2014). Pada teori klasik, skor yang diperoleh dan presentase jawaban benar selalu bersifat linear padahal hal tersebut tidak selalu menunjukkan linear (DeMArs, 2010; Qaseem, 2013; Kohli, dkk., 2014; Hambleton, Swaminathan \& Roger dalam Retnawati, 2014; Sumintono \& Widhiarso, 2015). Rasch Model sebagai hasil pengembang dari item response theory memiliki asumsi invariansi parameter artinya parameter butir soal tidak bergantung pada distribusi parameter kemampuan peserta didik dan parameter peserta didik tidak bergantung dari parameter butir soal (DeMArs, 2010; Qaseem, 2013; Kohli, dkk., 2014; Hambleton, Swaminathan \& Roger dalam Retnawati, 2014).

Dari pemaparan di atas dapat dinyatakan bahwa kemampuan habits of mind sangat penting dimiliki oleh peserta didik sebagai salah satu indikator dalam kesuksesan akademik, tugas dan hubungan sosial (Costa \& Kallick, 2000; Campbell, 2006) sehingga perlu adanya penggalian, pelatihan dan pengembangan kemampuan tersebut. Oleh karena itu, tulisan ini bertujuan untuk mengidentifikasi kemampuan habits of mind peserta didik SMA dengan analisis Rasch Model. Hal ini dikarenakan pada penelitian sebelumnya, untuk mengetahui kemampuan habits of mind yang dimiliki oleh peserta didik khususnya pada pembelajaran fisika hanya menggunakan presentase untuk setiap kategori habits of mind yaitu berpikir kritis, berpikir kreatif dan regulasi diri. Sedangkan, dengan Rasch Model dapat diketahui kemampuan habits of mind yang dimiliki oleh setiap peserta didik untuk setiap kategori sehingga dapat membantu guru dalam menggali, melatihkan dan mengembangkan kemampuan yang dianggap kurang pada proses pembelajaran.

Metode penelitian yang digunakan pada penelitian ini adalah studi kasus. Kasus pada penelitian ini adalah kemampuan habits of mind yang dimiliki oleh peserta didik SMA sebagai hasil dari pembelajaran. Skema metode yang digunakan pada penelitian ini seperti Gambar 2. 


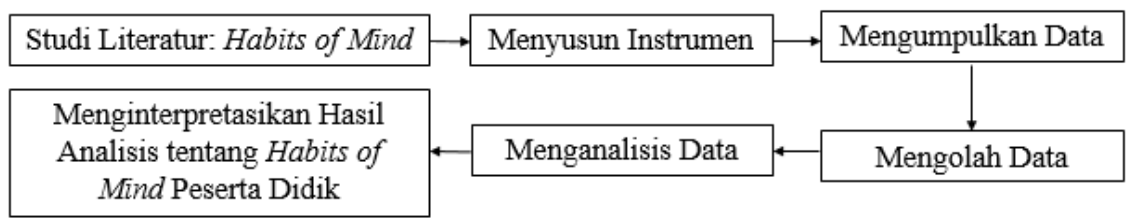

Gambar 2. Skema Metode Penelitian

Penelitian ini melibatkan partisipan sebanyak 36 orang peserta didik SMA kelas XI dengan rentang umur antara 16-17 tahun. Partisipan ini berasal suku sunda yang dipilih dengan menggunakan teknik random sampling karena setiap peserta didik bersifat homogen dan memiliki peluang yang sama untuk dijadikan sampel.

Instrumen penelitian yang digunakan adalah kuesioner habits of mind dan lembar observasi. Kuesioner habits of mind dikembangkan dengan mengacu pada rubik Marzano (1993) dan dinyatakan baik digunakan oleh ahli. Kuesioner habits of mind digunakan untuk menelusuri habits of mind yang dimiliki peserta didik. Instrumen ini berisi 15 pernyataan yang meliputi tiga kategori habits of mind yang dikemukan Marzano (1993), seperti Tabel 1.

Tabel 1. Distribusi Kuesioner Habits of Mind

\begin{tabular}{cc}
\hline Aspek Habits of Mind & Number \\
\hline Regulasi Diri & $1,2,3,4,5$ \\
Berpikir Kritis & $6,7,8,9,10,11$, \\
Berpikir Kreatif & $12,13,14,15$ \\
\hline
\end{tabular}

Setiap pernyataan memiliki 4 pilihan jawaban yang menunjukkan tingkat kemampuan habits of mind yang dimilik oleh peserta didik. Pilihan jawaban A bernilai 4 menunjukkan kemampuan habits of mind pada kategori yang sangat baik, pilihan jawaban B bernilai 3 menunjukkan kemampuan habits of mind pada kategori yang baik, pilihan jawaban $\mathrm{C}$ bernilai 2 menunjukkan kemampuan habits of mind pada kategori yang cukup baik dan pilihan jawaban D bernilai 1 menunjukkan kemampuan habits of mind pada kategori tidak baik. Berikut ini contoh instrumen kuesioner habits of mind, Gambar 3.

Saya mengetahui pemikiran saya.

A. Saya menggambarkan langkah-langkah pemikiran saya dengan sangat rinci ketika memecahkan masalah atau mengerjakan tugas.

B. Saya menggambarkan langkah-langkah pemikiran saya dengan cukup rinci ketika memecahkan masalah atau mengerjakan tugas.

C. Saya tidak menggunakan banyak sumber informasi ketika berusaha untuk memecahkan masalah atau mengerjakan tugas.

D. Saya menggambarkan pemikiran saya ketka memecahkan masalah atau mengerjakan tugas tetapi gambaran saya tersebut membingungkan.

\section{Gambar 3. Instrumen Kuesioner Habits of Mind}

Dengan menggunakan instrumen tersebut, diperoleh data berupa data ordinal hasil dari kuesioner dan data berupa catatan kegiatan dari lembar observasi. Data ordinal dianalisis dengan menggunakan Rasch Model berbantuan program Ministep versi 4.4.1 sehingga diperoleh kemampuan habits of mind yang dimiliki oleh peserta didik SMA. Adapun data catatan kegiatan dianalisis secara deskriptif sehingga diperoleh gambaran kegiatan yang mendukung kemampuan habits of mind yang dimiliki oleh peserta didik SMA. 


\section{Hasil dan Pembahasan}

Kemampuan habits of mind yang dimiliki peserta didik terdiri dari tiga kategori yaitu berpikir kritis, berpikir kreatif dan regulasi diri. Tingkat kemampuan habits of mind yang dimiliki oleh peserta didik ditunjukkan oleh nilai logit berdasarkan hasil analisis menggunakan Rasch Model berbantuan program Ministep versi 4.4.1. Nilai logit tersebut disusun dalam peta wright. Peta wright adalah peta yang menghubungkan kemampuan habits of mind yang dimiliki peserta didik dan tingkat kesukaran butir dalam skala yang sama (Sumintono \& Widhiarso, 2015). Peta wright sebelah kiri menunjukkan tingkat kemampuan habits of mind yang dimiliki oleh peserta didik SMA, sedangkan peta wright sebelah kanan menunjukkan tingkat kesukaran butir. Semakin atas posisi dari peserta didik SMA maka semakin tinggi kemampuan habits of mind yang dimilikinya (Sumintono \& Widhiarso, 2015). Begitu pula untuk butir soal, semakin atas posisi butir soal maka semakin sukar soal tersebut untuk dikerjakan (Sumintono \& Widhiarso, 2015). Berikut ini sebaran peta wright yang menunjukkan kemampuan habits of mind yang dimiliki peserta didik untuk setiap kategori.

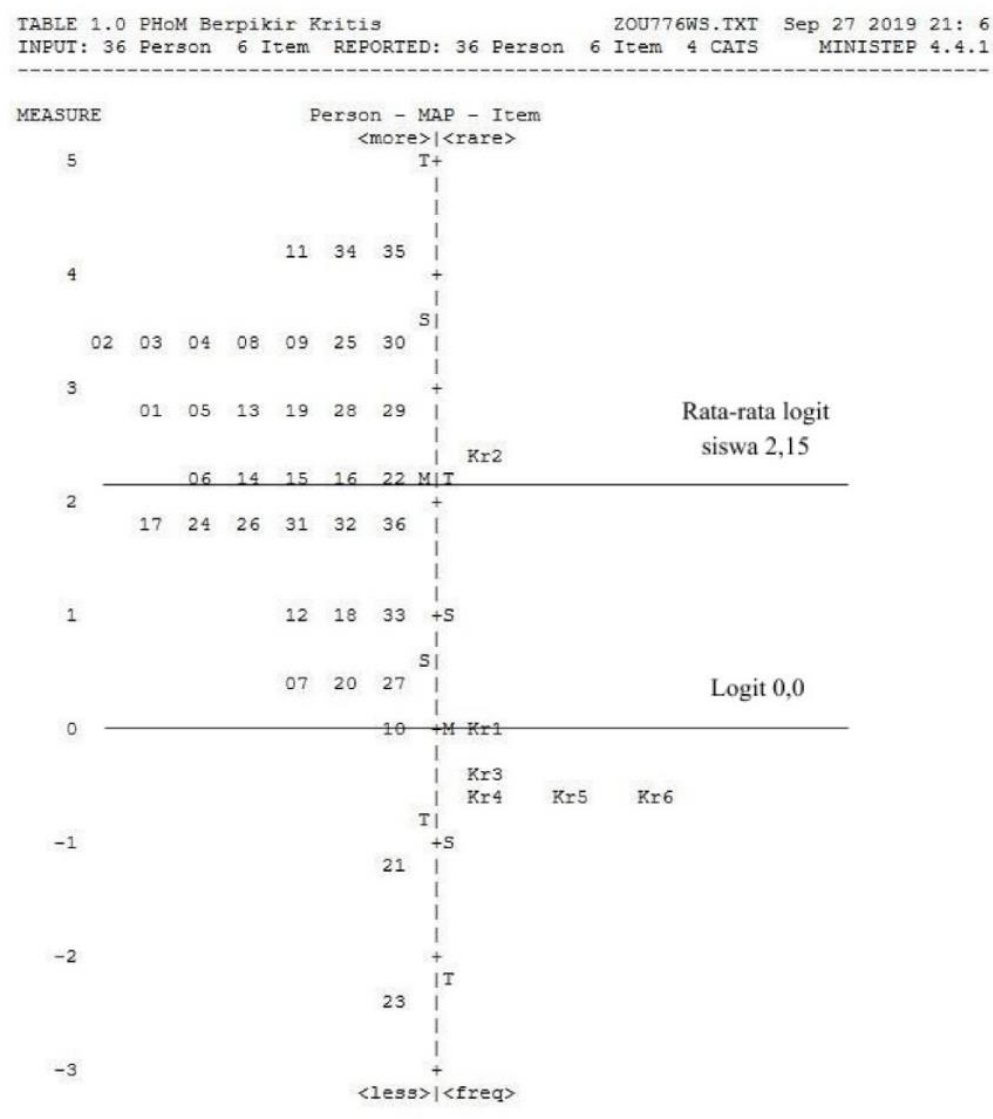

Gambar 4 Peta Wright Habits of Mind Kategori Berpikir Kritis

Gambar 3 menunjukkan kemampuan rata-rata habits of mind kategori berpikir kritis yang dimiliki peserta didik SMA berada pada logit $+2,15$. Sebagian besar dari partisipan memiliki kemampuan habits of mind kategori berpikir kritis di atas rata-rata. Peserta didik yang memiliki kemampuan habits of mind kategori berpikir kritis yang tinggi adalah peserta didik berkode 11, 34 dan 35 dengan logit $+4,26$. Berdasarkan nilai logit, peserta didik tersebut memiliki habits of mind kategori berpikir kritis yang tinggi sehingga peserta didik berpeluang besar untuk berada pada tingkat habits of mind kategori berpikir kritis dengan kategori baik yang ditunjukkan dengan nilai 3 bahkan kategori sangat baik yang ditunjukkan nilai 4 untuk setiap aspek. Peserta didik yang memiliki kemampuan habits of mind kategori berpikir kritis yang rendah adalah peserta didik berkode 23 dengan logit $-2,31$. Berdasarkan nilai logit, peserta didik tersebut memiliki habits of mind 
kategori berpikir kritis yang sangat rendah sehingga peserta didik berpeluang untuk berada pada habits of mind kategori berpikir kritis dengan kategori kurang baik yang ditunjukkan nilai 1 untuk setiap aspek.

Habits of Mind kategori berpikir kritis berdasarkan Gambar 4 tersebut sesuai dengan hasil penelitian yang dilakukan oleh Susilowati (2018) bahwa secara statistik untuk habits of mind kategori berpikir kritis yang dimiliki oleh peserta didik berada pada rata-rata nilai 3,06 dari 4,00. Nilai rata-rata tersebut dapat diasumsikan bahwa sebagian besar siswa memiliki habits of mind kategori berpikir kritis dengan nilai 3 dan nilai 4. Penemuan tersebut sesuai dengan hasil observasi pada pembelajaran bahwa dalam menghadapi masalah, peserta didik bersifat terbuka untuk berdiskusi mencari solusi yang jelas dan akurat.

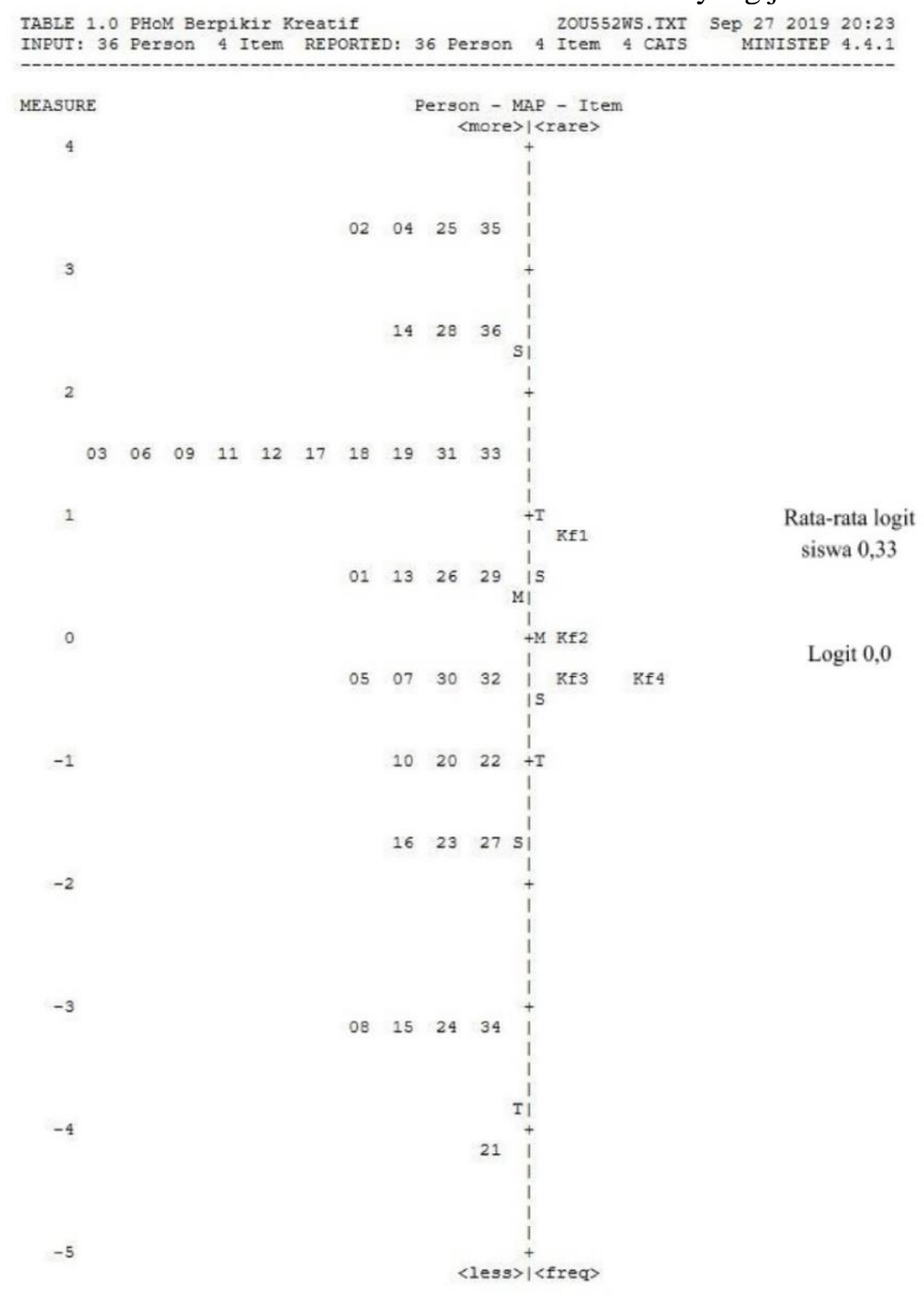

Gambar 5. Peta Wright Habits of Mind Kategori Berpikir Kreatif

Gambar 5 menunjukkan kemampuan rata-rata habits of mind berpikir kreatif yang dimiliki oleh peserta didik berada pada logit $+0,33$. Sebagian besar dari partisipan memiliki kemampuan di atas rata-rata. Peserta didik yang memiliki kemampuan habits of mind berpikir kreatif yang tinggi adalah peserta didik berkode 02, 04, 25 dan 35 dengan logit $+3,40$. Berdasarkan nilai logit, peserta didik tersebut memiliki habits of mind berpikir kreatif yang tinggi sehingga peserta didik berpeluang besar untuk berada pada tingkat habits of mind berpikir kreatif dengan kategori baik yang ditunjukkan dengan nilai 3 bahkan kategori sangat baik yang ditunjukkan nilai 4 untuk setiap aspek. Peserta didik yang memiliki kemampuan habits of mind berpikir kreatif yang rendah adalah siswa berkode 21 dengan logit $-4,14$. Berdasarkan nilai logit, peserta tersebut memiliki habits 
of mind berpikir kreatif yang sangat rendah sehingga peserta didik tersebut berpeluang untuk berada pada habits of mind berpikir kreatif dengan kategori kurang baik yang ditunjukkan nilai 1 untuk setiap aspek.

Habits of mind kategori berpikir kreatif berdasarkan Gambar 5 tersebut kurang sesuai dengan hasil penelitian yang dilakukan oleh Susilowati (2018) bahwa secara statistik untuk habits of mind berpikir kreatif yang dimiliki oleh peserta didik berada pada rata-rata nilai 2,96 dari 4,00. Nilai rata-rata tersebut dapat diasumsikan bahwa sebagian besar peserta didik memiliki habits of mind berpikir kreatif dengan nilai 3 . Perbedaan hasil penelitian tersebut dapat diakibatkan oleh proses pembelajaran dan karakteristik peserta didik yang berbeda. Pada penelitian proses pembelajaran yang dilakukan oleh guru membuat peserta didik aktif sehingga peserta didik terlibat untuk memecahkan masalah dan terlatih untuk berpikir kreatif.

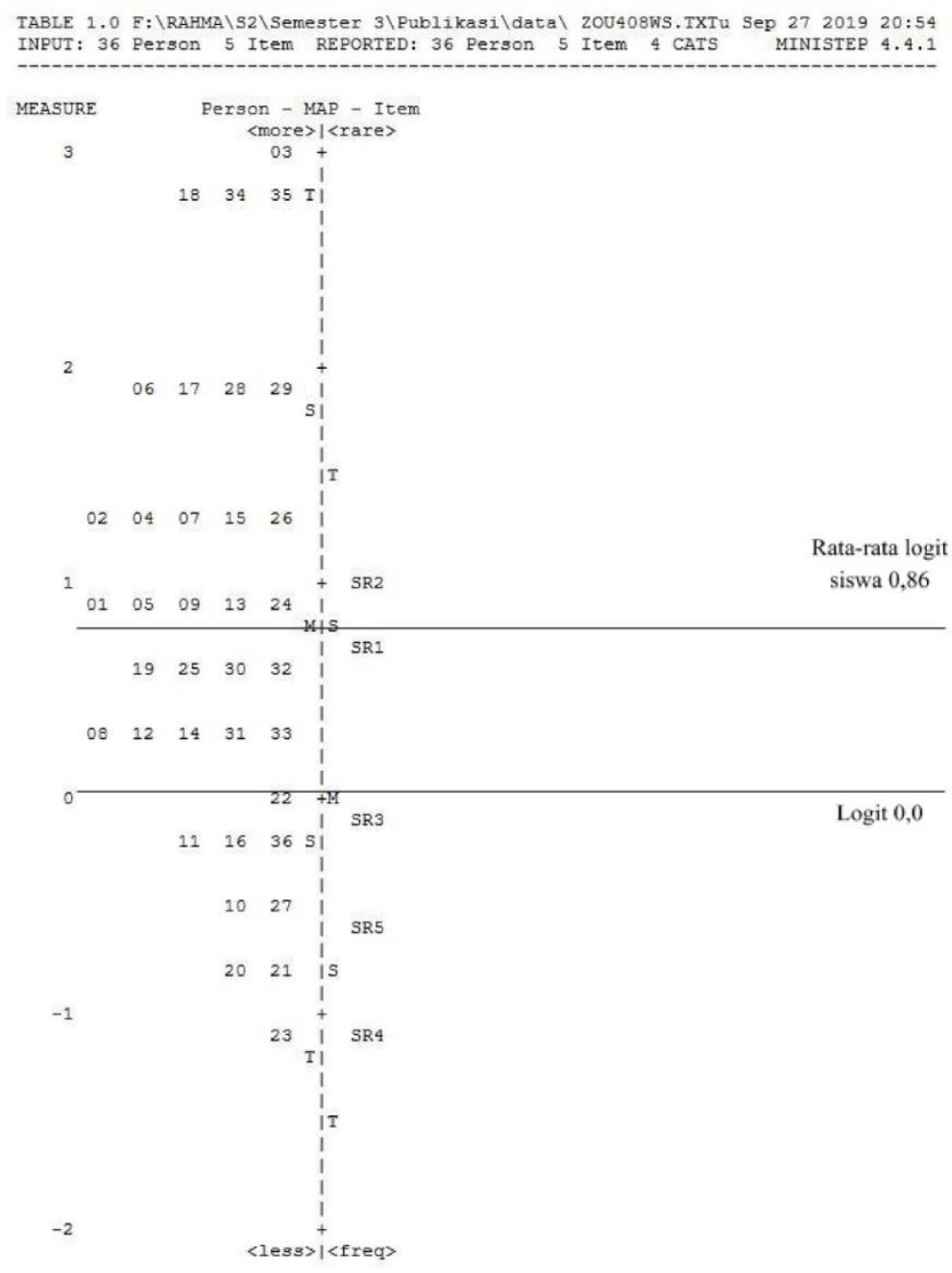

Gambar 6. Peta Wright Habits of Mind Kategori Regulasi Diri

Gambar 6 menunjukkan kemampuan rata-rata habits of mind kategori regulasi diri yang dimiliki oleh peserta didik berada pada logit $+0,86$. Sebagian besar dari partisipan berada pada kemampuan di bawah rata-rata. Peserta didik yang memiliki kemampuan habits of mind kategori regulasi diri yang tinggi adalah peserta didik berkode 03 dengan nilai logit $+4,12$. Berdasarkan nilai logit, peserta didik tersebut memiliki habits of mind kategori regulasi diri yang sangat tinggi sehingga peserta didik berpeluang besar untuk berada pada tingkat habits of mind kategori regulasi diri dengan kategori sangat baik yang ditunjukkan nilai 4 . Peserta didik yang memiliki kemampuan habits of mind kategori regulasi diri yang rendah adalah peserta didik berkode 23 dengan nilai logit $-1,09$. Berdasarkan nilai logit, peserta didik tersebut memiliki habits of mind kategori regulasi diri yang rendah sehingga peserta didik berpeluang untuk berada pada habits of mind 
kategori regulasi diri dengan kategori cukup baik yang ditunjukkan nilai 2 atau kurang baik yang ditunjukkan nilai 1.

Habits of mind kategori regulasi diri berdasarkan Gambar 6 tersebut tidak sesuai dnegan hasil penelitian yang dilakukan oleh Susilowati (2018) bahwa secara statistik untuk habits of mind kategori regulasi diri yang dimiliki oleh peserta didik berada pada rata-rata nilai 3,18 dari 4,00. Nilai rata-rata tersebut dapat diasumsikan bahwa sebagian besar peserta didik memiliki habits of mind kategori regulasi diri dengan nilai 3 dan nilai 4.

Penemuan tersebut sesuai dengan hasil observasi pada pembelajaran bahwa dalam menghadapi masalah, peserta didik hanya berfokus pada sumber yang ada bukan pada yang dibutuhkan dan tidak sensitif terhadap feedback yang diberikan oleh guru. Feedback merupakan salah satu strategi penilaian proses dalam pembelajaran yang dapat memperbaiki pembelajaran menjadi efektif dan dapat meningkatkan kemampuan peserta didik.

\section{$4 \quad$ Kesimpulan}

Setiap peserta didik memiliki tingkatan kemampuan habits of mind yang berbeda untuk setiap kategori. Untuk habits of mind kategori berpikir kritis dan habits of mind kategori berpikir kreatif sebagian besar dari partisipan di atas rata-rata atau dapat dinyatakan memiliki habits of mind yang baik sedangkan untuk habits of mind kategori regulasi diri, sebagian besar dari partisipan di bawah rata-rata atau dapat dinyatakan memiliki habits of mind yang kurang baik.

Dari penelitian ini direkomendasikan untuk dilakukan pembelajaran yang melatihkan habits of mind. Salah satu strategi yang dapat dilakukan adalah asesmen formatif, karena pada asesmen ini dapat meningkatkan kemampuan peserta didik dan perbaikan pembelajaran melalui feedback, self-assessment dan peerassessment.

\section{Daftar Pustaka}

Bee, M. S. H., Seng, H. G., \& Jusoff K. (2013). Habits of Mind in the ESL Classroom. English Language Teaching DOI:10.5539/elt.v6n11p130

Black, P and Wiliam, D. (1998). Assessment and Classroom Learning. Assessment in Education: Principles, Policy \& Practice 5(1) DOI: 10.1080/0969595980050102

Bjorner, J. B., Kosinski, M., \& Ware, J. E., Jr. (2003). Calibrationof an item pool for assessing the burden of headaches: anapplication of item response theory to the Headache Impact Test (HIT ${ }^{\mathrm{TM}}$ ). Qual. Life Res. 12 DOI: $10.1023 / \mathrm{A}: 1026163113446$

Bolt, D. M., Hare, R. D., Vitale, J. E., \& Newman, J. P. (2004). A multigroup item response theory analysis of the psychopathy checklist-revised. Psychol. Assess. 16 DOI: 10.1037/1040-3590.16.2.155

Campbell, J. (2006). Theorising Habits of mind as a Framework for Learning. Central Queensland University.

Costa, A. L. (1991). Teaching and Assessing Habits of mind. National Institute of Education Library, Singapore.

Costa A. L., \& Kallick, B. (1998). Habits of Mind in the Curriculum. Education for Meaning and Social Justice

Costa, A. L. \& Bena, K. (2000). Describing 16 Habits of mind. A Developmental Series. Alexandria VA. Diakses dari:

HYPERLINK

"http://www.ccsnh.edu/documents/CCSNHMLC.HabitsofMindCostaKallick"

www.ccsnh.edu/documents/CCSNHMLC.HabitsofMindCostaKallick .

DeMars, C. (2010). Item response theory. Series in Understanding Statistics. Oxford University Press, Inc. Madison Avenue, New York 
Dikli, S. (2003). Assessment at a distance: Traditional vs. Alternative Assessments. The Turkish Online Journal of Educational Technology (TOJET) ISSN: 1303-6521

Gloria, R. Y., et al. (2017). Formative Assessment with Stages of Understanding by Design (UbD) in Improving Habits of Mind. International Journal of Environmental \& Science Education 2233-2242

Griffin, P dkk. (2012). Assessment and Teaching of 21st Century Skills. Spinger.

Hamayan, E. V. (1995) Approaches to Alternative Assessment. Annual Review of Applied Linguistics DOI $10.1017 / \mathrm{S} 0267190500002695$

Hayat, M. S et al. (2018). Profile of Life-long Learning of Prospective Teacher in Learning Biology. IOP Conf. Series: Journal of Physics: Conf. Series 1157 (2019) 022083 DOI:10.1088/1742$6596 / 1157 / 2 / 022083$

Hizqiyah, I. Y. N., et al. (2018). Developing Habits of Mind through Web Based Learning Approach. Advances in Social Science, Education and Humanities Research. 3rd Asian Education Symposium (AES 2018)

Hofstein, A., \& Mamlok-Naaman, R. (2007). The Laboratory in Science Education: The State of The Art. Chemistry Education Research and Practice.

Hwang, G. Hung, C \& Chen, N. (2014). Improving Learning Achievements, Motivations and ProblemSolving Skills Through a Peer Assessment-based Game Development Approach. Education Tech Research Development 62 DOI 10.1007/s11423-013-9320-7

Jiang S, Wang C \& Welss D J. (2016). Sample Size Requirements for Estimation of Item Parameneters in the Multidimensional Graded Response Model. Front. Psychol DOI: 10.3389/fpsyg.2016.00109

Kohli, N., dkk. (2014). Relationships among classical test theory and item response theory frameworks via factor analytic models. Journal Educational and Psychological Measurement

Kuo, T. \& Sheng, Y. (2016). A Comparison of Estimation Methodes for a Multi-unidimensional Graded Response IRT Model. Front. Psychol. DOI: 10.3389/fpsyg.2016.00880

Marzano, R.J. (1992). A Different Kind of Classroom : Teaching with Dimensions of Learning. Association for Supervision and Curriculum Development, Alexandria, Va.

Marzano, R. J. et. al. (1993). Assessing Student Outcomes : Performance Assessment Using the Dimentions of Learning Model. Mid-Continent Regional Educational Lab., Aurora, CO.

Marzano, R. J et. al. (1997). Dimension of Learning Trainer's Manual,2nd Ed, Aurora, Colorado: McREL.

Nahadi, Firman, H., \& Farina, J. (2015). Effect of Feedback in Formative Assessment in the Students Learning Activities on Chemical Course to the Formation of Habits of Mind. Indonesian Journal of Science Education DOI: 10.15294/jpii.v4i1.3499

Neo, C.E., \& Cheung, W.S. (2005). The impact of directed viewing-thinking activity on students' critical thinking: Part II. New Horizons in Education. 52.

Panadero, E \& Romero, M. (2014). To Rubric or Not To Rubric? The Effects of Self-Assessment on SelfRegulation, Performance and Self-Efficacy. Assessment in Education: Principles, Policy \& Practice 21 (2) DOI: 10.1080/0969594X.2013.877872

Qasem, M. A. N. (2013). A Comparative Study of Classical Theory (Ct) and Item Response Theory (IRT) In Relation To Various Approaches of Evaluating the Validity and Reliabilitsy of Research Tools. IOSR Journal of Research \& Method in Education, 3 (5).

Retnawati, H. (2014). Teori Respons Butir dan Penerapannya. Yogyakarta: PT. Parama Publishing.

Shavelson, R. J, Zlatkon-Troitschanskaian O \& Marino J. P. (2018). International Performance Assessment of Learning in Higher Education (iPAL) : Research and Development. Assessment of Learning Outcomes in Higher Education, Methodology of Educational Measurement and Assessment DOI: 10.1007/978-3-319-74338-7_10

Sadler D. R. (1989). Formative Assessment and The Design of Instrutional Systems. Instructional Science 18 Sumintono, S \& Widhiarso, W. (2015). Aplikasi Pemodelan Rasch pada Assessment Pendidikan. Cimahi : Penerbit Trim Komunikata

Susilowati, E et al. (2018). Profile Habits of Mind Students in Physics Learning. IOP Conf. Series: Journal of Physics: Conf. Series 1120 (2018) 012055 doi:10.1088/1742-6596/1120/1/012055

Volkmann, M. J \& Eichinger, D. C. (1999). Habits of Mind: Integrating the Social and Personal Characteristics of Doing Science Into the Science Classroom. School Science and Mathematics. 